\title{
Identification of Resistance to Races of Puccinia graminis f. sp. tritici with Broad Virulence in Triticale (×Triticosecale)
}

P. D. Olivera, Department of Plant Pathology, University of Minnesota, St. Paul 55108; Z. A. Pretorius, Department of Plant Sciences, University of the Free State, Bloemfontein 9300, South Africa; A. Badebo, Ethiopian Institute of Agricultural Research (EIAR), Debre Zeit, Ethiopia; and Y. Jin, United States Department of Agriculture-Agricultural Research Service, Cereal Disease Laboratory, St. Paul, MN 51108

\begin{abstract}
Olivera, P. D., Pretorius, Z. A., Badebo, A., and Jin, Y. 2013. Identification of resistance to races of Puccinia graminis f. sp. tritici with broad virulence in triticale ( $\times$ Triticosecale). Plant Dis. 97:479-484.

Triticale ( $\times$ Triticosecale), an amphiploid of wheat (mainly Triticum turgidum) and cereal rye (Secale cereale), is an excellent source of resistance to wheat stem rust, caused by Puccinia graminis f. sp. tritici. A collection of 567 triticale accessions originating from 21 countries was evaluated at the seedling stage for reaction to races of $P$. graminis f. sp. tritici with broad virulence, including TTKSK, TRTTF, and TTTTF. A high frequency (78.4\%) of accessions was resistant to race TTKSK, with low infection types ranging from 0 ; to $\mathrm{X}$. A selection of 353 TTKSK-resistant accessions was evaluated for reaction to three South African isolates of $P$. graminis f. sp. tritici with single and/or combined virulences to stem rust resistance genes $\mathrm{SrSatu}, \mathrm{Sr} 27$, and $\mathrm{SrKw}$ present in triticale. Genes SrSatu, Sr27, and $\mathrm{SrKw}$ were postulated to be present in 141 accessions and contributed to TTKSK

resistance. The remaining 212 resistant accessions may possess uncharacterized genes or combinations of known genes that could not be determined with these isolates. These accessions were further evaluated for resistance to races TTKST, TPMKC, RKQQC, RCRSC, QTHJC, QCCSM, and MCCFC. Resistance remained effective across the entire set of races in the majority of the accessions $(n=200)$, suggesting that the resistances are effective against a broad spectrum of virulence. In all, 129 (79.6\%) resistant accessions with noncharacterized genes were resistant to moderately resistant in field stem rust nurseries at Debre Zeit (Ethiopia) and St. Paul (Minnesota). Results from evaluating $F_{2}$ populations derived from resistant-susceptible crosses revealed that resistance to TTKSK in triticale was conferred mostly by single genes with dominant effects.
\end{abstract}

Stem rust, caused by Puccinia graminis f. sp. tritici, is one of the most destructive diseases of durum (Triticum turgidum L. subsp. durum) and common or bread wheat (T. aestivum L.) worldwide. In particular, a group of races that emerged recently in eastern Africa possesses virulence to many currently grown wheat cultivars worldwide, and only a few genes in adapted cultivars are effective against these races $(6,7,22,27)$. Since it was first reported in 1999 (24), race TTKSK (Ug99) and its variants have been found throughout eastern and southern Africa $(8,14,27,32,33,35)$ and Iran (15). The lack of resistance in adapted germplasm, coupled with the rapid evolution and spread of this race group, urgently requires the identification and introgression of effective resistance genes into wheat. Wild and cultivated relatives of wheat are known to be good sources of stem rust resistance genes. A number of resistance genes derived from wild relatives of wheat appeared to be more effective against the races in the TTKS race group than $\mathrm{Sr}$ genes of wheat origin $(7,28)$.

Triticale $(\times$ Triticosecale $)$ is an intergeneric hybrid between wheat and rye (Secale cereale). Triticale was first developed in the late 19th century in Europe (34), and the first commercial cultivars were released in the 1960s $(5,10)$. Triticale is now grown commercially mostly in Europe, China, and Australia, mainly for livestock feed grain or grazing (11). Two types of triticale are grown and

\section{Corresponding author: Y. Jin, E-mail: yue.jin@ARS.USDA.GOV}

* The $\boldsymbol{e}$-Xtra logo stands for "electronic extra" and indicates that four supplementary figures and one supplementary table are available online.

Accepted for publication 5 October 2012.

http://dx.doi.org/10.1094/PDIS-05-12-0459-RE

This article is in the public domain and not copyrightable. It may be freely reprinted with customary crediting of the source. The American Phytopathological Society, 2013. used in breeding programs: primary triticale, which are the product of the wheat-rye hybridization followed by chromosome doubling; and secondary triticale, which result from intercrossing primary triticale or crossing primary triticale with wheat or rye (9). Tetraploid $(2 \mathrm{n}=2 \mathrm{x}=28)$, hexaploid $(2 \mathrm{n}=6 \mathrm{x}=42)$, and octoploid $(2 \mathrm{n}=$ $8 x=56$ ) triticale have been developed by crossing rye with diploid, tetraploid, and hexaploid wheat (4) but hexaploids are the main cultivated form. Hexaploid triticale lines are classified as complete or substitution types. Complete types have an entire rye genome, whereas substitution types have at least one set of rye chromosomes replaced by D-genome chromosomes from hexaploid wheat (3). Triticale is also a good resource of genes for wheat improvement, because it can be used as a bridge to transfer desirable characteristics of rye into wheat $(25,37)$. Triticale is a source of resistance to wheat stem rust, and several resistance genes have been described, including Sr27, SrNin, SrSatu, SrBj, and SrVen (13). Previous studies demonstrated that chromosomes $2 \mathrm{R}$ and $3 \mathrm{R}$ are important carriers of stem rust resistance genes in hexaploid triticale (1). The objective of this study was to identify and characterize stem rust resistance in triticale effective against race TTKSK and other races with broad virulence.

\section{Materials and Methods}

Plant materials. In total, 567 accessions of triticale from 21 countries deposited at the United States Department of Agriculture-Agricultural Research Service, National Small Grain Collection ([NSGC], Aberdeen, ID) were evaluated in this study (Table 1). Six triticale accessions were selected for inheritance and allelism studies. Four accessions (PI 271074, PI 410803, PI 414970, and PI 428980) were used as the resistant parents and two accessions (PI 386128 and PI 414945) were used as the susceptible parents. In total, eight crosses were developed to investigate the number of genes controlling resistance or to determine the relationship between resistance genes. $F_{1}$ plants were grown and selfed to produce $F_{2}$ populations. $F_{2}$ populations were evaluated for reaction to races TTKSK and TTTTF. 
Disease assessment. Seedling evaluations. All accessions were evaluated for reaction to three $P$. graminis $\mathrm{f}$. $\mathrm{sp}$. tritici races with broad virulence and different geographic origin: TTKSK (Kenya), TRTTF (Yemen), and TTTTF (United States). Accessions exhibiting resistance to race TTKSK were evaluated for their reaction to three South African P. graminis f. sp. tritici isolates of race BPGSC with virulence, individually or in combinations, to resistance genes

Table 1. Number and origin of triticale accessions used to evaluate stem rust resistance in triticale

\begin{tabular}{lcc}
\hline Location & Number of accessions & Percentage \\
\hline Russian Federation & 123 & 21.7 \\
Poland & 88 & 15.7 \\
Ukraine & 31 & 5.5 \\
Sweden & 32 & 5.6 \\
Germany & 11 & 1.9 \\
France & 11 & 1.9 \\
Spain & 22 & 3.9 \\
Hungary & 26 & 4.6 \\
Bulgaria & 25 & 4.4 \\
India & 26 & 4.6 \\
China & 19 & 3.4 \\
Australia & 25 & 4.4 \\
U.S.A. & 61 & 10.8 \\
Mexico & 59 & 10.4 \\
Others & 7 & 1.2 \\
Total & 567 & 100 \\
\hline
\end{tabular}

a One accession each came from Pakistan, England, Finland, Switzerland, Italy, Portugal, and Romania.
SrSatu, Sr27, and SrKw that are known to be present in triticale (isolates UVPgt53 [virulence to $\mathrm{Sr} 27$ ], UVPgt56 [virulence to $\mathrm{Sr} 27$ and $\mathrm{SrKw}$ ], and UVPgt57 [virulence to $\mathrm{Sr} 27, \mathrm{SrKw}$, and $\mathrm{SrSatu}$ ]). $\mathrm{SrKw}$ is an uncharacterized gene in the South African triticale 'Kiewiet'. The resistant accessions with uncharacterized genes were further evaluated for resistance to race TTKST (virulence to Sr24) (8) from Kenya and six additional U.S. races (TPMKC, RKQQC, RCRSC, QTHJC, QCCSM, and MCCFC). Information about the $P$. graminis $\mathrm{f}$. sp. tritici isolates used in the disease phenotyping tests is summarized in Table 2 . The fully expanded primary leaves of 5 to 10 seedlings per accession were inoculated 8 to 9 days after planting. Experimental procedures in inoculation and disease assessment were described by Jin et al. (7) and Pretorius et al. (22). Wheat 'McNair 701' (Cltr 15288) was planted in each experiment as the susceptible check. All disease assessments were repeated.

Adult evaluation. A subset of 168 accessions that were selected for resistance to race TTKSK and South African P. graminis f. sp. tritici races was evaluated in field stem rust nurseries in St. Paul, MN (April to July 2010) and Debre Zeit, Ethiopia (June to October 2010). In St. Paul, the nursery was inoculated with a composite of six U.S. races (TPMKC, RKQQC, RCRSC, QTHJC, QFCSC, and MCCFC). In Debre Zeit, the nursery was inoculated with race TTKSK and a bulk of Ethiopian isolates (with unknown race identities) collected from durum lines at the Debre Zeit Research Center at a ratio of 50/50. Details about the management of nurseries at St. Paul and Debre Zeit, and inoculation and disease assessment procedures, were described by Olivera et al. (18).

Table 2. Isolate designation, origin, and virulence phenotype of Puccinia graminis f. sp. tritici races used to evaluate resistance in triticale

\begin{tabular}{|c|c|c|c|}
\hline Race & Isolate & Origin & Virulence/avirulence formula \\
\hline TTKSK & 04KEN156/04 & Kenya & Sr5 6 7b 8a 9a 9b 9d 9e 9g 10111721303138 McN/Sr24 36 Tmp \\
\hline TTKST & 06KEN19-V-3 & Kenya & Sr5 6 7b 8a 9a 9b 9d 9e 9g 1011172124303138 McN/Sr36 Tmp \\
\hline TRTTF & 06YEM34-1 & Yemen & Sr5 6 7b 9a 9b 9d 9e 9g $10111721303638 \mathrm{McN}$ Tmp/Sr8a 2431 \\
\hline TTTTF & $02 \mathrm{MN} 84 \mathrm{~A}-1-2$ & United States & Sr5 6 7b 8a 9a 9b 9d 9e 9g $10111721303638 \mathrm{McN}$ Tmp/Sr24 31 \\
\hline TPMKC & 74MN1409 & United States & Sr5 7b 8a 9d 9e 9g $1011172136 \mathrm{McN}$ Tmp/Sr6 9a 9b 24303138 \\
\hline RKQQC & 99KS76A-1 & United States & Sr5 6 7b 8a 9a 9b 9d 9g $2136 \mathrm{McN} / 9 \mathrm{e} 10111724303138 \mathrm{Tmp}$ \\
\hline RCRSC & 77ND82A & United States & Sr5 7b 9a 9b 9d 9g $10172136 \mathrm{McN} / 6$ 8a 9e $1124303138 \mathrm{Tmp}$ \\
\hline QTHJC & $75 \mathrm{ND} 717 \mathrm{C}$ & United States & Sr5 6 8a 9b 9d 9g $10111721 \mathrm{McN} / 7 \mathrm{~b} 9 \mathrm{a} 9 \mathrm{e} 2430313836 \mathrm{Tmp}$ \\
\hline QCCSM & 75WA165-2A & United States & Sr5 9a 9d 9g $10172124 \mathrm{McN} / 6$ 7b 8a 9b 9e $1130313638 \mathrm{Tmp}$ \\
\hline MCCFC & $59 \mathrm{KS} 19$ & United States & Sr5 7b 9g $1017 \mathrm{McN}$ Tmp/6 8a 9a 9b 9d 9e 11212430313638 \\
\hline BPGSC & UVPgt53 & South Africa & Sr8a 9a 9b 9d 9g $1011 \mathrm{McN} / 56$ 7b 9e 17212430313638 Tmp \\
\hline BPGSC & UVPgt56 & South Africa & Sr8a 9a 9b 9d 9g $1011 \mathrm{McN} / 56$ 7b 9e 17212430313638 Tmp \\
\hline BPGSC & UVPgt57 & South Africa & Sr8a 9a 9b 9d 9g $1011 \mathrm{McN} / 56$ 7b 9e $17212430313638 \mathrm{Tmp}$ \\
\hline
\end{tabular}

Table 3. Number and percentage of triticale accessions exhibiting resistant, susceptible, and heterogeneous reaction to Puccinia graminis f. sp. tritici races TTKSK, TRTTF, and TTTTF

\begin{tabular}{|c|c|c|c|c|c|c|}
\hline \multirow[b]{2}{*}{$\mathbf{I T}^{\mathbf{a}}$} & \multicolumn{2}{|c|}{ TTKSK } & \multicolumn{2}{|c|}{ TRTTF } & \multicolumn{2}{|c|}{ TTTTF } \\
\hline & $N$ & $\%$ & $N$ & $\%$ & $N$ & $\%$ \\
\hline 0 & 57 & 10.1 & 38 & 6.7 & 60 & 10.6 \\
\hline ; & 212 & 37.5 & 151 & 26.6 & 150 & 26.5 \\
\hline ;1 & 36 & 6.4 & 48 & 8.5 & 67 & 11.9 \\
\hline 1 & 7 & 1.2 & 21 & 3.7 & 19 & 3.4 \\
\hline $2=$ & 39 & 6.9 & 10 & 1.8 & 34 & 6.0 \\
\hline $2-$ & 50 & 8.8 & 59 & 10.4 & 64 & 11.3 \\
\hline 2 & 26 & 4.6 & 76 & 13.4 & 40 & 7.1 \\
\hline $2+$ & 2 & 0.4 & 3 & 0.5 & 4 & 0.7 \\
\hline 3 & 16 & 2.8 & 17 & 3.0 & 34 & 6.0 \\
\hline $3+$ & 33 & 5.8 & 27 & 4.8 & 41 & 7.3 \\
\hline 4 & 26 & 4.6 & 57 & 10.1 & 9 & 1.6 \\
\hline $\mathrm{X}$ & 14 & 2.5 & 0 & 0.0 & 1 & 0.2 \\
\hline Total resistant ${ }^{\mathrm{b}}$ & 443 & 78.4 & 406 & 71.6 & 439 & 77.7 \\
\hline Total susceptible & 75 & 13.3 & 101 & 17.8 & 84 & 14.9 \\
\hline Heterogeneous ${ }^{\mathrm{d}}$ & 47 & 8.3 & 60 & 10.6 & 42 & 7.4 \\
\hline
\end{tabular}

${ }^{a}$ Infection types (ITs) observed on seedlings at 14 days post inoculation using a 0-to-4 scale according to Stakman et al. (30); the range of ITs is shown in Supplementary Figure S1.

${ }^{\mathrm{b}}$ Resistant corresponds to low ITs of $0, ;, 1,2, \mathrm{X}$, or combinations thereof.

c Susceptible corresponds to high ITs of 3 or 4 .

$\mathrm{d}$ Accessions that contained both resistant and susceptible plants. 
Inheritance studies. To determine the genetic control of resistance to wheat stem rust at the seedling stage, crosses between resistant and susceptible triticale accessions were produced. $F_{2}$ populations were evaluated for reaction to races TTKSK and TTTTF to assess gene action and determine the inheritance of resistance based on phenotypic ratios. Tests of allelism were made using $\mathrm{F}_{2}$ populations derived from crosses between resistant accessions. The $\chi^{2}$ test was applied to determine the goodness-of-fit to expected genetic ratios in the $\mathrm{F}_{2}$ generation.

Table 4. Infection types (ITs) to South African races of Puccinia graminis f. sp. tritici in triticale accessions selected for resistance to race TTKSK, and stem rust resistance $(R)$ genes postulated to be present in these accessions

\begin{tabular}{|c|c|c|c|c|c|}
\hline \multirow[b]{2}{*}{ Numberb } & \multicolumn{4}{|c|}{ ITs to $P$. graminis f. sp. tritici isolates ${ }^{\mathrm{a}}$} & \multirow[b]{2}{*}{ Postulated known $R$ gene } \\
\hline & 04KEN156/04 & UVPgt53 & UVPgt56 & UVPgt57 & \\
\hline 27 & $; 2=$ & 1 & 4 & 4 & $S r K w^{\mathrm{c}}$ \\
\hline 2 & $2-;$ & $11-$ & 1 & 1 & SrKw + additional gene \\
\hline 42 & ; & ; & ; & 4 & $S r S a t u^{\mathrm{d}}$ \\
\hline 30 & ; & ; & ; & 1 or 2 & SrSatu + additional gene $e^{\mathrm{e}}$ \\
\hline 39 & ; & $3+$ or 4 & $3+$ or 4 & $3+$ or 4 & Sr27 \\
\hline 1 & ; & $2+$ & $33+$ & $2+, 4$ & Sr27 + additional gene \\
\hline 212 & $\ldots$ & $\ldots$ & $\ldots$ & $\ldots$ & Uncharacterized genes \\
\hline
\end{tabular}

${ }^{a}$ ITs observed on seedlings at 14 days post inoculation using a 0-to-4 scale according to Stakman et al. (30), where ITs of ;, 1, 2, or X are considered as a low IT and ITs of 3 or higher are considered as a high IT. Race designation of isolate 04KEN156/04 is TTKSK and race designation of isolates UVPgt53, UVPgt56, and UVPgt57 is BPGSC.

${ }^{\mathrm{b}}$ Number of triticale accessions.

${ }^{\mathrm{c}}$ ITs were shown in Supplementary Figure S2.

${ }^{\mathrm{d}}$ ITs were shown in Supplementary Figure S3.

${ }^{\mathrm{e}}$ ITs were shown in Supplementary Figure S4.

Table 5. Infection types (ITs) of triticale ( $\times$ Triticosecale) accessions evaluated to races TTKSK, TTKST, TRTTF, TTTTF, TPMKC, RKQQC, RCRSC, QTHJC, QCCSM, and MCCFC of Puccinia graminis f. sp. tritici grouped according to the country of origin ${ }^{\mathrm{a}}$

\begin{tabular}{|c|c|c|c|c|c|c|c|c|c|c|c|c|}
\hline Country & $\mathbf{P I}^{\mathbf{b}}$ & Cultivar or line & $\begin{array}{c}\text { TTKSK } \\
\text { 04KEN156/04 }\end{array}$ & $\begin{array}{c}\text { TTKST } \\
\text { 06KEN19-V-3 }\end{array}$ & $\begin{array}{c}\text { TRTTF } \\
\text { 06YEM34-1 }\end{array}$ & $\begin{array}{c}\text { TTTTF } \\
\text { 01MN84A-1-2 }\end{array}$ & $\begin{array}{l}\text { TPMKC } \\
\text { 74MN1409 }\end{array}$ & $\begin{array}{c}\text { RKQQC } \\
\text { 99KS76A-1 }\end{array}$ & $\begin{array}{c}\text { RCRSC } \\
\text { 77ND82A }\end{array}$ & $\begin{array}{l}\text { QTHJC } \\
\text { 75ND717C }\end{array}$ & $\begin{array}{r}\text { QCCSM } \\
\text { 75WA165-2A }\end{array}$ & $\begin{array}{c}\text { MCCFC } \\
59 \mathrm{KS} 19\end{array}$ \\
\hline Australia & 525197 & Muir & 0 & ;N & ;CN & ;CN & 0 & ;N & 0 & 0 & 0 & 0 \\
\hline Australia & 587261 & $81-220$ & $2=$ & $2=; / ; \mathrm{N}$ & $2-$ & $2=$ & $12=$ & $2=$ & $2=$ & $2-$ & $2=$ & $2-;$ \\
\hline Bulgaria & 564431 & $11776-163$ & $22+$ & $2+2$ & 4 & $3+$ & 3 & $3-3 / 1$ & $3-3$ & $3-$ & 3 & $3-3$ \\
\hline Canada & 429049 & $278-9$ & $2=$ & $2=$ & $22-$ & $2-/ 3$ & $2-;$ & $2=$ & $; 2=1$ & ;N & ;N & ;CN \\
\hline China & 428933 & 2 & ;CN & $2-$ & $2-1$ & $2-1$ & $2-$ & $2-;$ & $2-;$ & $2-; / ; \mathrm{CN}$ & $2-$ & $2-; \mathrm{CN}$ \\
\hline China & 610224 & 237 & $3 ; 1$ & $1 ; 3$ & $2 / 3 ; 1$ & 2 & $1 ; 3$ & $2-$ & ;13 & $2-13$ & $2-$ & 213 \\
\hline France & 429013 & 539 & $2=$ & $2-$ & $2-$ & $2-1 ; \mathrm{CN}$ & $2-$ & $2-$ & $2-;$ & $2-$ & $2-$ & $; 2=$ \\
\hline Germany & 429097 & $6 \mathrm{~A}-694$ & $2-; \mathrm{CN} 1$ & $2=$ & ;CN & ;CN1- & $2-;$ & ;C & ;C & $; \mathrm{C} 2=$ & ;C2 $=$ & $; 2=$ \\
\hline Hungary & 428980 & Szalkas & 0 & ;N & 0 & $; \mathrm{CN}$ & ;N & 0 & 0 & 0 & 0 & 0 \\
\hline India & 358312 & Triticale 1 & $23-$ & 213 & $3-2$ & $1-; \mathrm{CN}$ & 31 & $2-$ & $; 2=$ & 31 & $2-2$ & $32 ; / ; 2+$ \\
\hline India & 429094 & 75TP-242- & & & & & & & & & & \\
\hline & & JNK6T-227 & ;CN & ;N & ;CN & ;CN1- & ;N & 0 & 0 & 0 & 0 & ;N \\
\hline Mexico & 611454 & Beagle 'S' 505 & $2-$ & $3-1$ & 2 & $2-$ & $2-$ & $; 1$ & $; 1$ & $2-2 ; 3$ & ;N & $2=$ \\
\hline Mexico & 611783 & $\begin{array}{l}\text { 710037-10D-2TL- } \\
\text { 4D-20D-1D-0D }\end{array}$ & $2=$ & $2=$ & $22-$ & $2=$ & 2 & :C & $: \mathrm{N}$ & :CN & $: \mathrm{N}$ & :C \\
\hline Mexico & 611786 & 710039-0D-4TL- & & & & & & & & & & \\
\hline & & 4D-1D-2D-0D & 0 & ;N & 0 & 0 & ; & ;C & 0 & 0 & ;C & 0 \\
\hline Mexico & 611798 & $\begin{array}{c}\text { X-15733-0M- } \\
\text { 0D-PC291 }\end{array}$ & ;13 & $31 ;$ & 2 & 2 & $1 ; 3$ & $; 1$ & $; 12=/ ; 13$ & $; 13$ & $; 1$ & $1 ; 3$ \\
\hline Poland & 410803 & LT $344 / 72$ & $2-$ & $2-;$ & $2+$ & $2-$ & $1-2=$ & 0 & ;N & $; \mathrm{N}$ & ;N & $; \mathrm{N}$ \\
\hline Poland & 429072 & LT $140 / 72$ & 0 & ;N & 0 & 0 & ;N & 0 & 0 & ;N & 0 & ;N \\
\hline Poland & 429138 & LT $332 / 75$ & 2 & $2-$ & 4 & $22-$ & $1 ; 3$ & $22-$ & $2 ; 3$ & $2-; / 23$ & ;13 & $2+3$ \\
\hline Poland & 564439 & Lasko & 0 & ;N & ;CN1- & ;CN & ;N & ;N & $; \mathrm{N}$ & ;CN & ;N & $; \mathrm{CN}$ \\
\hline Portugal & 611339 & Borba & 2 & $31 ;$ & $3-2$ & 2 & $123-$ & ;13 & ;13 & $; 23 / 23$ & ;13 & $2 ; 3-$ \\
\hline Romania & 587224 & TF 3 & 0 & ;N & $2=$ & ;CN & ;N & 0 & 0 & 0 & ;N & 0 \\
\hline Russian Fed. & 386003 & $31 \mathrm{AD} 72$ & 2 & $2-2$ & $3+$ & 2 & 2 & $2-/ 3$ & $22-/ 3+$ & 2 & 2 & $2 / 33$ \\
\hline Russian Fed. & 414958 & PRAG 31/2 & ;C & ;1- & ;C & ;C1- & $2-;$ & ;C & ;CN & ;CN & ;C & $; 2=$ \\
\hline Russian Fed. & 217074 & Pisarevs 1 & $22-$ & 2 & 2 & $2-; \mathrm{C}$ & $2-$ & $2=$ & $2=$ & $2-$ & ;C & $2-$ \\
\hline Russian Fed. & 428855 & HAD 259 & 2 & $2-2$ & $22-$ & $2-$ & $2-2$ & $2-;$ & $2-;$ & $22+$ & $2-;$ & 2 \\
\hline Russian Fed. & 572943 & PRAG 46/6 & ;CN & ;N & ;CN & ;CN1- & $; 2=$ & ;C1- & ;C2 $=$ & $; \mathrm{C} 2=$ & $\mathrm{C}$ & $; 2=$ \\
\hline Spain & 256033 & Triticale 1 & $22-$ & $2-1$ & $22-$ & $2-1$ & $2-1$ & $2-;$ & $2-;$ & $2-;$ & $2=$ & $2-;$ \\
\hline Spain & 428821 & MTE 58 & ;C1- & ;C & $; \mathrm{C} / 2=$ & ;C1- & ;C & ;C & ;C & ;C & ;C & $; \mathrm{CN}$ \\
\hline Spain & 428897 & Sel. 4 & ;C & ;C & ;C1- & ;C & $2-;$ & $2-;$ & $2=$ & $2=;$ & ;N & ;N \\
\hline Sweden & 429063 & $8 \mathrm{~A}-653$ & ;CN & $; \mathrm{N}$ & ;C1-2= & ;CN1- & ;N & 0 & 0 & 0 & ;N & ;N \\
\hline Ukraine & 386127 & AD K2 & $; 13$ & 312 & $22-/ 3+$ & ;12-/3+ & 31 & $3 / 2=$ & $3 ; / 2=$ & $2-/ 32$ & 31 & $31 / 2$ \\
\hline Ukraine & 429275 & Dneprovskij & $2-1$ & $2=; / 33+$ & $2-1 ; \mathrm{CN}$ & $1-; \mathrm{CN}$ & $2-; / 3-$ & $2-;$ & $2-;$ & $2-;$ & ;N/3 & ;2- \\
\hline Ukraine & 445677 & AD 767-16 & ;13 & ;23- & 4 & 4 & 31 & ;13 & 32 & ;13/3+ & ;C1 & $1 ; 3 / 3+$ \\
\hline Ukraine & 572929 & AD 19 & $; 13$ & $2-/ 312$ & $2 / 4$ & ;CN / 4 & $2-/ 31$ & $2-$ & $2-;$ & $2-;$ & $2-; / ; \mathrm{C}$ & $; 2-$ \\
\hline United States & 587536 & $6 \mathrm{~TB} 2 \mathrm{Q}$ & 0 & ;N & 0 & ;CN & ;N & 0 & 0 & ;N & 0 & ;N \\
\hline United States & 611847 & H7089-1-9-5 & $2=$ & $2=$ & $22+$ & 2 & $2-$ & $2-;$ & ;2- & $2-;$ & $2-;$ & $; 2-$ \\
\hline United States & 634195 & Mammoth II & 2 & $3-1$ & 2 & ;CN2= & $2-13$ & ;C & ;C & $; 13$ & ;C & ;13- \\
\hline
\end{tabular}

${ }^{a}$ ITs observed on seedlings at 14 days post inoculation using a 0-to-4 scale according to Stakman et al. (30), where ITs of ;, 1, 2, or X are considered as a low IT and ITs of 3 or higher are considered as a high IT. $\mathrm{N}$ denotes excessive necrosis. " $"$ " indicated accessions were heterogeneous with dominant type given first.

b Plant introduction (PI) number. 


\section{Results}

Seedling evaluation. A high frequency of resistance was observed in triticale; 443 (78.4\%), $406(71.6 \%)$, and $439(77.7 \%)$ accessions exhibited low infection types (ITs), to P. graminis f. sp. tritici races TTKSK, TRTTF, and TTTTF, respectively (Table 3). A wide range of ITs (from 0; to $\mathrm{X}$ ) was observed in the resistant accessions (Table 3; Supplementary Figure S1). However, very low ITs $(0 ;$ to ; 1$)$ were predominant (Table 3 ; Supplementary Table S1). Resistance genes $\mathrm{SrKw}, \mathrm{SrSatu}$, and $\mathrm{Sr} 27$, known to be present in triticale, were postulated in 141 of the 353 TTKSK-resistant accessions based on differential reactions to South African $P$. graminis f. sp. tritici isolates (Table 4; Supplementary Figures S2 to S4). The remaining 212 resistant accessions may possess combinations of known genes that could not be detected with these isolates, or previously uncharacterized genes. The majority of these accessions $(n=200)$ exhibited low ITs to all $P$. graminis $\mathrm{f}$. $\mathrm{sp}$. tritici races used in this study. A subset of resistant lines showing characteristic ITs to the 10 races evaluated is presented in Table 5.

Adult plant evaluation. In Debre Zeit, triticale entries were evaluated during the main cereal-growing season (May to October). During these months, conditions were conducive for stem rust development, and a high level of disease severity was observed in the nursery. Susceptible checks (wheat 'Red Bobs') ranged from $50 \mathrm{SMS}$ to $70 \mathrm{~S}$ across the nursery, and susceptible triticale reached disease severities up to $60 \mathrm{MSS}$. Race-typing experiments of isolates collected from the Debre Zeit nursery indicated that race TTKSK was the predominant race (19). A high level of stem rust severity was obtained in the St. Paul field nursery. Susceptible checks (wheat 'LMPG-6') exhibited a disease severity across the nursery of $60 \mathrm{~S}$ to $80 \mathrm{~S}$, whereas susceptible triticale reached severities from 30 SMS to $50 \mathrm{~S}$. More than $80 \%$ of the TTKSKresistant accessions exhibited resistant $(\mathrm{R})$ to moderately resistant (MR) responses in St. Paul and Debre Zeit nurseries (Table 6). Although the inoculum used in both field nurseries differed in race composition, no major differences were observed in the frequency and level of resistance. In all, 108 (64.3\%) and 110 (65.5\%) entries displayed disease responses within the range 0 to $20 \mathrm{R}$ in St. Paul and Debre Zeit, respectively (Table 6).

Inheritance and allelism studies. The segregation ratios observed in the $F_{2}$ progeny from three crosses between resistant and susceptible accessions fitted 3:1 ratios for resistance/susceptibility to race TTKSK (Table 7), indicating that resistance to race TTKSK at the seedling stage in the selected accessions is controlled by a single gene with complete dominance. The simple inheritance of TTKSK resistance in the selected triticale resistant parents should simplify the transfer of resistance to wheat. In the cross involving accession PI 271074 as resistant parent, the segregation ratio between resistant and susceptible $\mathrm{F}_{2}$ plants did not fit the single-gene hypothesis $(P$ value $=0.027)$ due to a higher number of susceptible plants (64:34) (Table 7). The segregation distortion is likely a result of preferential transmission of gametes of the susceptible parent. To identify additional stem rust resistance genes in triticale, we evaluated $\mathrm{F}_{2}$ populations from crosses between resistant and susceptible parents for their reaction to race TTTTF. One gene with complete dominance effective to race TTTTF was observed in

Table 6. Number and percentage of triticale accessions exhibiting resistant (R), moderately resistant (MR), moderately susceptible (MS), and susceptible (S) response at the adult stage at field stem rust nurseries in St. Paul, MN, and Debre Zeit, Ethiopia

\begin{tabular}{|c|c|c|c|c|c|}
\hline \multicolumn{2}{|c|}{ Disease evaluation } & \multicolumn{2}{|c|}{ St. Paul, MN } & \multicolumn{2}{|c|}{ Debre Zeit, Ethiopia } \\
\hline Infection response ${ }^{a}$ & Severity ${ }^{b}$ & $N$ & $\%$ & $N$ & $\%$ \\
\hline $\mathrm{R}$ & $0-20$ & 108 & 64.3 & 110 & 65.5 \\
\hline $\mathrm{R}$ & $21-40$ & 0 & 0.0 & 0 & 0.0 \\
\hline RMR-MRR & $0-30$ & 26 & 15.5 & 20 & 11.9 \\
\hline RMR-MRR & $31-60$ & 0 & 0.0 & 0 & 0.0 \\
\hline MR & $0-30$ & 13 & 7.7 & 10 & 6.0 \\
\hline MR & $31-60$ & 0 & 0.0 & 1 & 0.6 \\
\hline MRMS-MSMR & $0-30$ & 11 & 6.5 & 6 & 3.6 \\
\hline MRMS-MSMR & $31-60$ & 0 & 0.0 & 3 & 1.8 \\
\hline MS & $0-30$ & 2 & 1.2 & 7 & 4.2 \\
\hline MS & $31-60$ & 1 & 0.6 & 0 & 0.0 \\
\hline MSS-SMS & $0-30$ & 3 & 1.8 & 4 & 2.4 \\
\hline MSS-SMS & $31-60$ & 2 & 1.2 & 2 & 1.2 \\
\hline $\mathrm{S}$ & $0-30$ & 0 & 0.0 & 4 & 2.4 \\
\hline $\mathrm{S}$ & $31-60$ & 2 & 1.2 & 1 & 0.6 \\
\hline Total & $\ldots$ & 168 & 100 & 168 & 100 \\
\hline
\end{tabular}

${ }^{a}$ Infection response is determined based on pustule type and size (26).

${ }^{\mathrm{b}}$ Stem rust severity following the modified Cobb scale (20).

Table 7. Segregation of $\mathrm{F}_{2}$ populations of various crosses of triticale to Puccinia graminis $\mathrm{f}$. sp. tritici races TTKSK and TTTTF

\begin{tabular}{|c|c|c|c|c|c|c|}
\hline \multirow[b]{2}{*}{ Cross $^{\mathrm{a}}$} & \multirow[b]{2}{*}{ Race } & \multicolumn{5}{|c|}{$\mathbf{F}_{2}$ plants } \\
\hline & & Resistant & Susceptible & Ratio tested & $\chi^{2}$ & $P$ value \\
\hline PI $386128($ IT = 3+) × PI $271074($ IT = 22-) & TTKSK & 64 & 34 & $3: 1$ & 4.912 & 0.027 \\
\hline PI $386128($ IT $=3+) \times$ PI $410803($ IT = 2-) & TTKSK & 105 & 28 & $3: 1$ & 1.105 & 0.293 \\
\hline PI $414945((I T=4) \times$ PI $428980($ IT = 0; $)$ & TTKSK & 108 & 30 & $3: 1$ & 0.783 & 0.376 \\
\hline PI $414945(I T=4) \times$ PI $414970(I T=22+)$ & TTKSK & 114 & 32 & $3: 1$ & 0.740 & 0.390 \\
\hline PI $386128($ IT $=3+) \times$ PI $271074($ IT = 2) & TTTTF & 16 & 53 & $1: 3$ & 0.121 & 0.728 \\
\hline PI $386128(\mathrm{IT}=3+) \times$ PI $410803(\mathrm{IT}=2-)$ & TTTTF & 72 & 29 & $3: 1$ & 0.743 & 0.389 \\
\hline PI $414945(\mathrm{IT}=4) \times$ PI $428980(\mathrm{IT}=0$; & TTTTF & 65 & 20 & $3: 1$ & 0.098 & 0.754 \\
\hline PI $414945($ IT = 4) × PI $414970($ IT = ;) & TTTTF & 93 & 6 & $15: 1$ & 0.006 & 0.938 \\
\hline PI 271074 (unknown gene) × PI $429151($ SrSatu) & TTKSK & 107 & 0 & $\ldots$ & $\ldots$ & $\ldots$ \\
\hline PI 410803 (unknown gene) $\times$ PI $429151($ SrSatu $)$ & TTKSK & 114 & 0 & . & $\ldots$ & $\ldots$ \\
\hline PI 414953 (SrSatu) × PI 428980 (unknown gene) & TTKSK & 72 & 3 & $15: 1$ & 0.648 & 0.421 \\
\hline PI 414953 (SrSatu) × PI 428980 (unknown gene) & TTTTF & 464 & 34 & $15: 1$ & 0.283 & 0.595 \\
\hline PI 271074 (unknown gene) × PI 410803 (unknown gene) & TTKSK & 114 & 0 & $\ldots$ & $\ldots$ & $\ldots$ \\
\hline
\end{tabular}

${ }^{\text {a }}$ Female parent $\times$ male parent. PI $=$ plant introduction. Infection types (ITs) observed on seedlings at 14 days post inoculation using a 0-to- 4 scale according to Stakman et al. (30). 
accessions PI 410803 and PI 428980, whereas one gene with recessive effect was identified in accession PI 271074 (Table 7). Two genes with complete dominance were detected in accession PI 414970 , one of which was postulated to be SrSatu when evaluated against the three South African isolates. Our results indicated that SrSatu is effective to both TTKSK and TTTTF, whereas the other resistance gene in PI 414970 is effective only to race TTTTF. In the allelism test, the $F_{2}$ populations derived from the crosses between resistant accessions with uncharacterized genes (PI 271074 and PI 410803) and accessions postulated to carry SrSatu produced only resistant progeny to race TTKSK (Table 7). These results indicated that these resistant accessions carry resistance genes that are allelic or tightly linked to $\mathrm{SrSatu}$. In addition, the $\mathrm{F}_{2}$ population derived from the cross between the two resistant accessions carrying uncharacterized genes (PI 271074 and PI 410803) produced only resistant progeny to race TTKSK (Table 7). This indicated that TTKSK resistance in both accessions is allelic. Accession PI 428980 carries a gene effective to race TTKSK that is not allelic to SrSatu (Table 7). Due to the limited number of $F_{2}$ plants in the TTKSK evaluation, the $F_{2}$ progeny of the cross between accessions PI 428980 and PI 414953 (with SrSatu) was also evaluated against race TTTTF. In both evaluations, progeny segregation between resistant and susceptible plants fitted the 15:1 ratio, indicating that the genes present in both accessions are not alleles.

\section{Discussion}

Race TTKSK of Puccinia graminis f. sp. tritici and its variants are a serious threat to bread and durum wheat production worldwide because of its wide virulence on many cultivars and rapid spread (27). Collective efforts in the wheat pathology and breeding community are being made to characterize and incorporate resistance genes effective against race TTKSK from durum and bread wheat and its relatives. Resistance to stem rust in triticale has been previously reported $(1,13,29,36)$ but reaction to the recently emerged race TTKSK and its variants has not been characterized. Our results demonstrated that triticale is a rich source of resistance to TTKSK and other races of $P$. graminis $\mathrm{f}$. sp. tritici. Previous studies on stem rust resistance in triticale documented a narrow genetic base of stem rust resistance in CIMMYT-derived materials $(11,29,36)$. The accessions we used in this study from NSGC included entries from European countries with large triticale breeding programs (e.g., Russian Federation, Poland, Germany, and France; 17), which may allow the capture of resistance genes different from those present in the CIMMYT triticale.

In all, 141 triticale accessions were postulated to carry $S r 27$, $\mathrm{SrSatu}$, or SrKw (Table 4). SrSatu and $\mathrm{Sr} 27$ are the most common stem rust resistance genes in CIMMYT triticale $(12,29,36)$ and are expected to be widely distributed because CIMMYT materials have played an important role in the improvement of triticale in many countries (36). The 108 triticale accessions resistant to race TTKSK were postulated to have $\mathrm{Sr} 27, \mathrm{SrSatu}$, or $\mathrm{SrKw}$ alone. This result confirmed that $S r 27, S r S a t u$, and $S r K w$ are effective against race TTKSK. However, virulence to $\mathrm{Sr} 27, \mathrm{SrSatu}$, and $\mathrm{SrKw}$ has been reported in Australia and South Africa $(12,23,38)$; therefore, use of these genes should be limited to areas where virulence to these genes is absent in the rust population. 'Abacus', an accession (PI 591912) from Australia, is known to carry resistance genes SrSatu and $\mathrm{SrBj}$ (1). Sixty-three accessions with uncharacterized genes exhibited an IT profile similar to Abacus when evaluated with races TTKSK $(\mathrm{IT}=; \mathrm{CN})$, TRTTF $(\mathrm{IT}=;)$, TTTTF $(\mathrm{IT}=;$ ) and the three South African $P$. graminis f. sp. tritici isolates (ITs =; and ;1) of race BPGSC. These accessions may carry $S r B j$ but a more definitive postulation of this gene will require evaluation with Australian races with and without virulence to $\operatorname{SrBj}$ (13).

Triticale accessions with uncharacterized genes exhibited a high level of resistance; that is, to races representing a broad range of virulence at the seedling stage (Table 5). Resistance identified from seedling tests remained highly effective in field evaluations (Table 6). Selection of resistance based on seedling tests is an effective way to identify resistance, because the stem rust resistance genes detected at the seedling stage remain effective at the adult stage. All the stem rust resistance genes described in triticale (13) appeared to be major-effect, all-stage resistance genes. Adult plant resistance genes have not been reported in the species. In this study, we conducted field evaluations of accessions that exhibited resistance to race TTKSK at the seedling stage. To look for genes for adult plant resistance in triticale, accessions susceptible at the seedling stage should be included in field evaluations.

We identified a resistance gene effective to race TTKSK in two resistant parents (PI 271074 and PI 410803) that is allelic or closely linked to SrSatu (Table 7). This locus on chromosome 3R carries multiple stem rust resistance alleles, including $\mathrm{SrSatu}, \mathrm{Sr} 27$, and SrLal $(1,29)$. One additional resistance gene effective to race TTTTF was present in accession PI 414970. The use of races with different virulence spectra proved to be an efficient tool to identify multiple stem rust resistance genes in individual accessions.

Triticale can contribute novel genes to increase the diversity of stem rust resistance. Efforts should be made to incorporate these effective genes from triticale into adapted common wheat backgrounds. However, the use of triticale genes to improve stem rust resistance in common wheat may also result in a negative impact if not deployed in effective gene combinations. If the same gene is used in both triticale and wheat, the occurrence of virulence to the gene in one crop would endanger the other (1). Resistance genes should be deployed in combination with other effective genes, preferably in backgrounds with complex stem rust resistance in order to prolong their effectiveness. The introgression of stem rust resistance genes from triticale into wheat by chromosomal recombination or translocation is a challenge for wheat breeders and cytogeneticists. The production of wheat-triticale hybrids is associated with a high proportion of aneuploids, sterility of $F_{1}$ plants, and low fertility in ensuing generations (16). However, resistance genes from triticale can be introgressed into wheat through hybridization and doubled-haploid breeding (21). The availability of a high-density linkage map in hexaploid triticale $(2,31)$ can serve as a useful tool to facilitate mapping and introgression of stem rust resistance genes.

\section{Acknowledgments}

This research was funded by the United States Department of AgricultureAgricultural Research Service and the Durable Rust Resistance of Wheat (DRRW), Cornell. We thank L. Wanschura, S. Gale, G. Hiwot Abraha, C. Steyn, and C. Bender for their technical assistance; and H. Bockelman, United States Department of Agriculture-Agricultural Research Service, National Small Grains Collection, Aberdeen, ID, for providing triticale seed.

\section{Literature Cited}

1. Adhikari, K. N., and McIntosh, R. A. 1998. Inheritance of wheat stem rust resistance in triticale. Plant Breed. 117:505-513.

2. Alheit, K. V., Reif, J. C., Maurer, H. P., Hahn, V., Weissmann, E. A., Miedaner, T., and Wurschum, T. 2011. Detection of segregation distortion loci in triticale ( $\times$ Triticosecale Wittmack) based on a high-density DArT marker consensus genetic linkage map. BMC Genomics 12:380.

3. Fox, P. N., Skovmand, B., Thompson, B. K., Braun, H.-J., and Cromier, R. 1990. Yield adaptation of hexaploid spring triticale. Euphytica 47:57-64.

4. Furman, B. J., Qualset, C. O., Skovmand, B., Heaton, J. H., Corke, H., and Wesenberg, D. M. 1997. Characterization and analysis of North American triticale genetic resources. Crop Sci. 37:1951-1959.

5. Hills, M. J., Hall, L. M., Messenger, D. F., Graf, R. J., and Beres, B. L. 2007. Evaluation of crossability between triticale $(\times$ Triticosecale Wittmack) and common wheat, durum wheat and rye. Environ. Biosafety Res. 6:249-257.

6. Jin, Y., and Singh, R. P. 2006. Resistance in U.S. wheat to recent eastern African isolates of Puccinia graminis f. sp. tritici with virulence to resistance gene Sr31. Plant Dis. 90:476-480.

7. Jin, Y., Singh, R. P., Ward, R. W., Wanyera, R., Kinyua, M., Njau, P., Fetch, T., Pretorius, Z. A., and Yahyaoui, A. 2007. Characterization of seedling infection types and adult plant infection responses of monogenic $\mathrm{Sr}$ gene lines to race TTKS of Puccinia graminis f. sp. tritici. Plant Dis. 91:1096-1099.

8. Jin, Y., Szabo, L. J., Pretorius, Z. A., Singh, R. P., Ward, R., and Fetch, T., Jr. 2008. Detection of virulence to resistance gene $S r 24$ within race TTKS of Puccinia graminis f. sp. tritici. Plant Dis. 92:923-926.

9. Kiss, A. 1966. Neue Richtung in der Triticale-Züchtung. Z. Pflanzenzuecht 55:309-329.

10. Later, E. N. 1995. Triticale. Pages 181-183 in: Evolution of Crop Plants, 2nd ed. J. Smartt and N. W. Simmonds, eds. Longman Scientific \& Tech- 
nical, Edinburgh.

11. McIntosh, R. A. 1988. The role of specific genes in breeding for durable stem rust resistance in wheat and triticale. Pages 1-9 in: Breeding Strategies for Resistance to the Rusts of Wheat. CIMMYT, Mexico D.F., Mexico.

12. McIntosh, R. A., Luig, N. H., Milne, D. L., and Cusick, J. 1983. Vulnerability of triticales to wheat stem rust. Can. J. Plant Pathol. 5:61-69.

13. McIntosh, R. A., Wellings, C. R., and Park, R. F. 1995. Wheat Rusts: An Atlas of Resistance Genes. Kluwer Academy Publishers, London.

14. Mukoyi, F., Soko, T., Mulima, E., Mutari, B., Hodson, D., Herselman, L., Visser, B., and Pretorius, Z. A. 2011. Detection of variants of wheat stem rust race Ug99 (Puccinia graminis f. sp. tritici) in Zimbabwe and Mozambique. Plant Dis. 95:1188.

15. Nazari, K., Mafi, M., Yahyaoui, A., and Park, R. F. 2009. Detection of wheat stem rust (Puccinia graminis f. sp. tritici) race TTKSK (Ug99) in Iran. Plant Dis. 93:317.

16. Nkongolo, K. K. 1996. Expression of barley yellow dwarf virus and Russian wheat aphid resistance genes in and fertility of spring wheat $\times$ triticale hybrids and backcross lines. Euphytica 90:337-344.

17. Oettler, G. 2005. The fortune of a botanical curiosity-triticale: past, present and future. J. Agric. Sci. 143:329-346.

18. Olivera, P. D., Badebo, A., Xu, S. S., Klindworth, D. L., and Jin, Y. 2012. Resistance to race TTKSK of Puccinia graminis f. sp. tritici in emmer wheat (Triticum turgidum ssp. dicoccum). Crop Sci. 52:2234-2242.

19. Olivera, P. D., Jin, Y., Rouse, M., Badebo, A., Fetch, T., Singh, R. P., and Yahyaoui, A. 2012. Races of Puccinia graminis f. sp. tritici with combined virulence to $\operatorname{Sr} 13$ and $\operatorname{Sr} 9 e$ in a field stem rust screening nursery in Ethiopia. Plant Dis. 96:623-628.

20. Peterson, R. F., Campbell, A. B., and Hannah, A. E. 1948. A diagrammatic scale for estimating rust intensity of leaves and stem of cereals. Can. J. Res. Sect. C 26:496-500.

21. Pratap, A., Sethi, G. S., and Chaudhary, H. K. 2006. Relative efficiency of anther culture and chromosome elimination techniques for haploid induction in triticale $\times$ wheat and triticale $\times$ triticale hybrids. Euphytica 150:339-345.

22. Pretorius, Z. A., Jin, Y., Bender, C. M., Herselman, L., and Prins, R. 2012. Seedling resistance to stem rust race $\mathrm{Ug} 99$ and marker analysis for $\mathrm{Sr}$, Sr24 and Sr31 in South African wheat cultivars and lines. Euphytica 186:15-23.

23. Pretorius, Z. A., Pakendorf, K. W., Marais, G. F., Prins., R, and Komen, J. S. 2007. Challenges for sustainable cereal rust control in South Africa. Aust. J. Agric. Res 58:593-601.

24. Pretorius, Z. A., Singh, R. P., Wagoire, W. W., and Payne, T. S. 2000. Detection of virulence to wheat stem rust resistance gene Sr31 in Puccinia graminis f. sp. tritici in Uganda. Plant Dis. 84:2003.
25. Qualset, C. O. 1985. Synthesis, breeding, adaptation, and utilization of triticale in California. Pages 71-82 in: Genetics and Breeding of Triticale. M. Bernard and S. Bernard, eds. Proc. 3rd EUCARPIA Meet. Triticale. Clermont-Ferrand, France.

26. Roelfs, A. P. Singh, R. P., and Saari, E. E. 1992. Rust Diseases of Wheat, Concepts and Methods of Disease Management. CIMMYT, Mexico D.F., Mexico.

27. Singh, R. P., Hodson, D. P., Huerta-Espino, J., Jin, Y., Bhavani, S., Njau, P., Herrera-Foessel, S. A., Singh, P., Singh, S., and Govindan, V. 2011. The emergence of Ug99 races of the stem rust fungus is a threat to world wheat production. Annu. Rev. Phytopathol. 49:465-481.

28. Singh, R. P., Hodson, D. P., Jin, Y, Huerta-Espino, J., Kinyua, M. G Wanyera, R., Njau, P., and Ward, R. W. 2006. Current status, likely migration and strategies to mitigate the threat to wheat production from race Ug99 (TTKS) of stem rust pathogen. CAB Rev. Perspect. Agric. Vet. Sci. Nutr. Nat. Res. 54:1-13

29. Singh, S. J., and McIntosh, R. A. 1988. Allelism of two genes for stem rust resistance in triticale. Euphytica 38:185-189.

30. Stakman, E. C., Stewart, D. M., and Loegering, Q. W. 1962. Identification of physiologic races of Puccinia graminis var. tritici. U. S. Dep. Agric. ARS E-617.

31. Tyrka, M., Bednarek, P. T., Killian, A., Wedzony, M., Hura, T., and Bauer, E. 2011. Genetic map of triticale compiling DArT, SSR, and AFLP markers Genome 54:391-401.

32. Visser, B., Herselman, L., Park, R. F., Karaoglu, H., Bender, C. M., and Pretorius, Z. A. 2011. Characterization of two new Puccinia graminis $\mathrm{f}$. sp. tritici races within the Ug99 lineage in South Africa. Euphytica 179:119127.

33. Wanyera, R., Kinyua, M. G., Jin, Y., and Singh, R. P. 2006. The spread of stem rust caused by Puccinia graminis f. sp. tritici, with virulence on $\mathrm{Sr} 31$ in wheat in Eastern Africa. Plant Dis. 90:113.

34. Wilson, A. S. 1876. Wheat and rye hybrids. Trans. Proc. Bot. Soc. Edinburgh 12:286-288.

35. Wolday, A., Fetch Jr., T., Hodson, D., Cao, W., and Briere, S. 2011. First report of Puccinia graminis f. sp. tritici races with virulence to wheat stem rust resistance genes $S r 31$ and $S r 24$ in Eritrea. Plant Dis. 95:1591.

36. Zhang, J., Wellings, C. R., McIntosh, R. A., and Park, R. F. 2010. Seedling resistance to rust diseases in international triticale germplasm. Crop Pasture Sci. 61:1036-1048.

37. Zhuang, Q. S., and Li, Z. S. 1993. Present status of wheat breeding and related genetic study in China. Wheat Inf. Serv. 76:1-15.

38. Zwer, P. K., Park, R. F., and McIntosh, R. A. 1992. Wheat stem rust in Australia 1969-1985. Aust. J. Agric. Res. 43:399-431. 